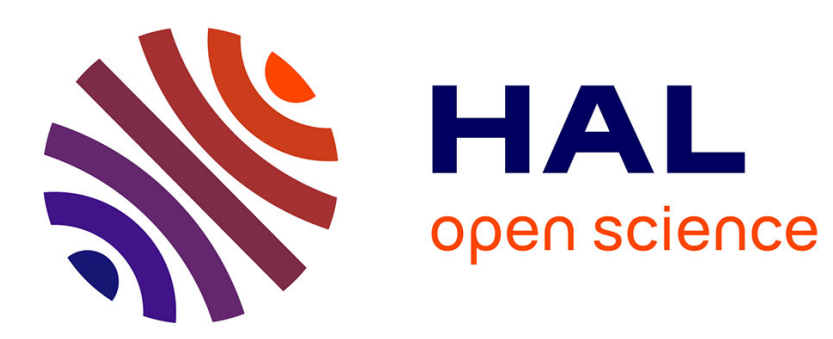

\title{
Elaboration and study of mechanically alloyed O.D.S. ferritic stainless steel
}

M. Bodart, R. Baccino, F. Moret

\section{To cite this version:}

M. Bodart, R. Baccino, F. Moret. Elaboration and study of mechanically alloyed O.D.S. ferritic stainless steel. Journal de Physique IV Proceedings, 1993, 03 (C7), pp.C7-709-C7-714. 10.1051/jp4:19937111 . jpa-00251729

\section{HAL Id: jpa-00251729 https://hal.science/jpa-00251729}

Submitted on 1 Jan 1993

HAL is a multi-disciplinary open access archive for the deposit and dissemination of scientific research documents, whether they are published or not. The documents may come from teaching and research institutions in France or abroad, or from public or private research centers.
L'archive ouverte pluridisciplinaire HAL, est destinée au dépôt et à la diffusion de documents scientifiques de niveau recherche, publiés ou non, émanant des établissements d'enseignement et de recherche français ou étrangers, des laboratoires publics ou privés. 


\title{
Elaboration and study of mechanically alloyed O.D.S. ferritic stainless steel
}

\author{
M. BODART, R. BACCINO and F. MORET
}

CEREM, Laboratoire de Génie des Matériaux, CENG, 85X, 38041 Grenoble cedex, France

\section{ABSTRACT}

O.D.S. ferritic stainless steel has been elaborated by mechanical alloying from elemental powders and fully characterized by SEM, TEM, EDS and XRD.

Macroscopic and microstructural evolutions of the material have been determined as a function of milling time. It has been observed that the changes in composition and structure are dramatic up to 40 milling hours. For higher milling durations, the powder characteristics are nearly unchanged.

Two kinds of reinforcing dispersoids have been identified by TEM on HIP compacted powders: titanium compounds $(50-200 \mathrm{~nm})$ in the grain boundaries and complex yttrium oxide nanometer sized particles inside the grains.

\section{INTRODUCTION}

Mechanical alloying, a powder metallurgy technique, can be used to produce metal matrix materials reinforced by ultrafine ceramic dispersions $[1,2,3]$. In this technique, metallic powders are repeatedly welded, fractured and rewelded in a high energy mill, giving birth to new particles with a characteristic layered structure [4]. Because of numerous shocks with steel balls, the layers become thinner and thinner until they can no longer be optically resolved. At that time, a correct degree of mechanical alloying is achieved. Milling with additional oxide particles introduce nanometer dispersoids between metallic layers resulting in an Oxide Dispersion Strengthened alloy (ODS) in which mechanical properties, mainly creep resistance, are enhanced by pinning of dislocations [5].

Due to their good swelling resistance, ferritic stainless steels can be candidates for nuclear fuel canning applications $[6,7]$ provided their creep strength could be improved $[8,9]$. The aim of our work was to develop the elaboration by mechanical alloying of such an ODS ferritic steel. Optimization of the process has been obtained by studying the effects of milling conditions on macroscopic and microstructural evolutions of the material.

\section{EXPERIMENTAL}

Starting materials were chemically pure $\mathrm{Fe}, \mathrm{Cr}, \mathrm{Ti}$, Mo and $\mathrm{Y}_{2} \mathrm{O}_{3}$ powders whose characteristics are given hereafter:

\begin{tabular}{cccccc} 
& $\mathrm{Fe}$ & $\mathrm{Cr}$ & $\mathrm{Ti}$ & $\mathrm{Mo}$ & $\mathrm{Y}_{2} \mathrm{O}_{3}$ \\
\hline Particle size $(\mu \mathrm{m})$ & $100-150$ & 300 & $<100$ & 4 & $<44$ \\
Weight $\%$ & bal. & 14 & 1 & 0.3 & 0.25
\end{tabular}

Mechanical alloying was carried out in a Netzsch PR01 attritor charged with $9.5 \mathrm{~kg}$ of $8 \mathrm{~mm}$ diameter $100 \mathrm{C} 6$ steel balls and $400 \mathrm{~g}$ of blended powders. Rotating speed was $400 \mathrm{rev} / \mathrm{min}$. Milling was performed under air and under argon atmosphere from 12 to 100 hours. 
Elaborated powders were characterized by optical and electron microscopy. Ultramicrotomy was used to prepare $60 \mathrm{~nm}$ thick sections for STEM examinations performed on a JEOL $2000 \mathrm{FX}$ microscope equipped with Energy Dispersive Spectroscopy (EDS) on a TRACOR 5400-B using MSCAN 2 (an Ximaging program). X-ray diffraction (XRD) was used to determine phases transformations within the powders. Oxide dispersion was observed on carbon replicas of consolidated powders after hot isostatic pressing (HIP).

\section{CHARACTERIZATION OF MILLED POWDERS}

\subsection{Morphology}

SEM photographs show that powder particles become considerably smaller with increasing milling time under air (fig.1). After a few hours, the powders consist of flaky particles with a mean diameter of 100-150 $\mu \mathrm{m}$. Afterwards, the particles become nearly spherical and their diameter decreases to approximatively 20-50 $\mu \mathrm{m}$. Further milling reduces the particles size down to a few micrometers (fig.2) At this size, the particles tend to agglomerate.
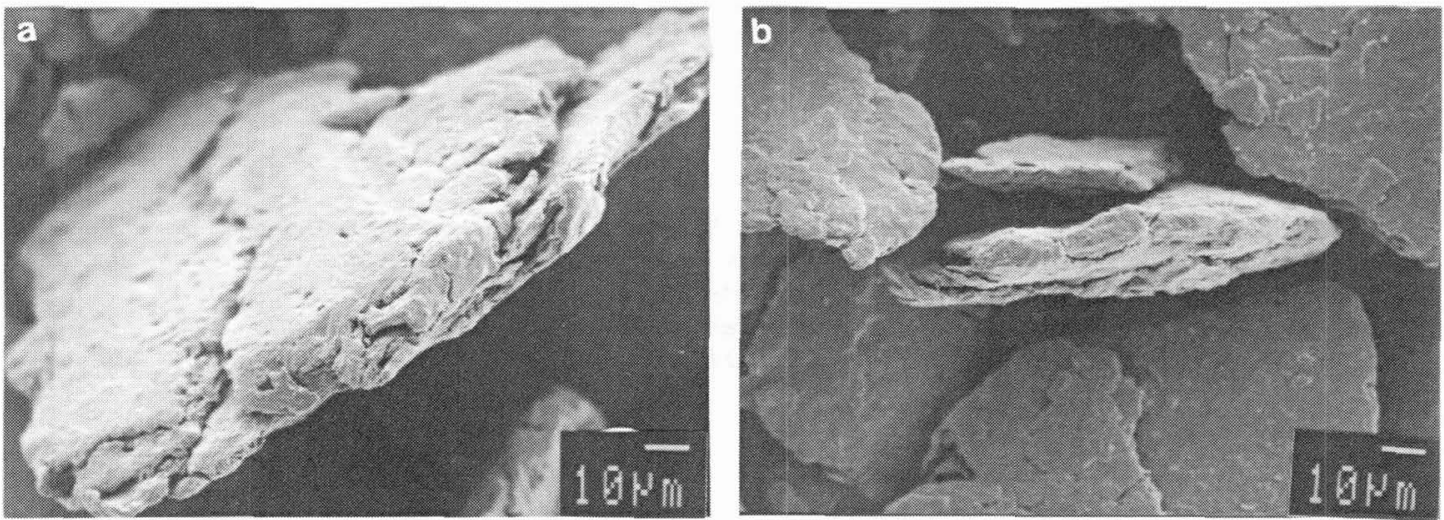

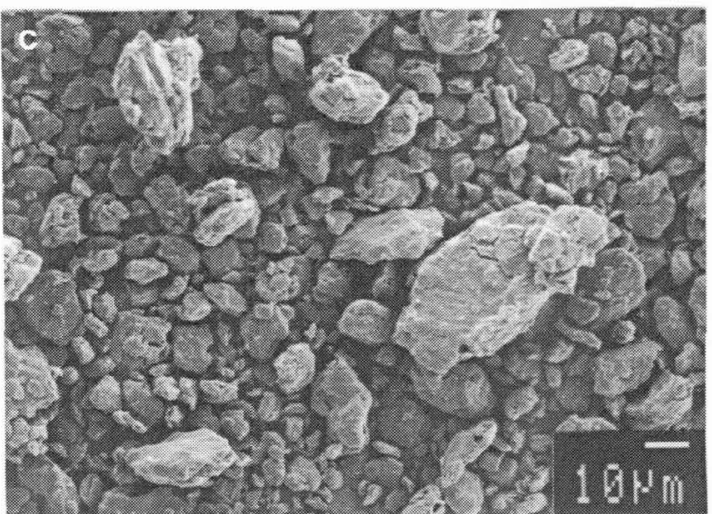

Fig.1: Evolution of powders morphology (a: $12 \mathrm{~h}, \mathrm{~b}: 20 \mathrm{~h}, \mathrm{c}: 40 \mathrm{~h}, \mathrm{~d}: 60 \mathrm{~h}$ )

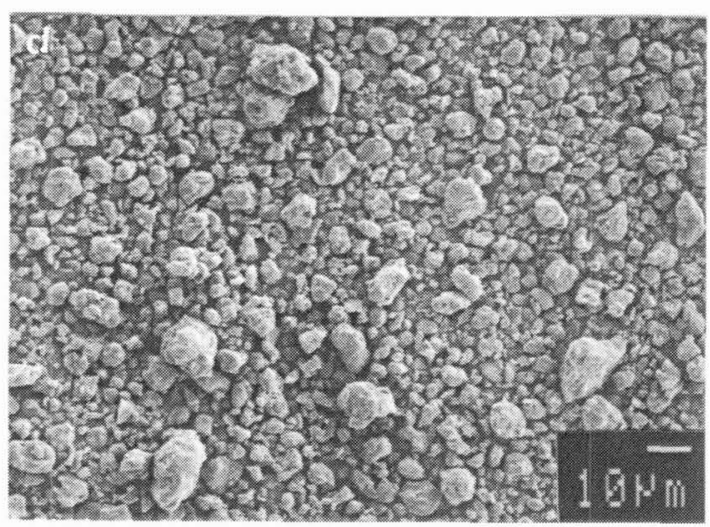

as a function of milling time under air

Fig. 3 shows powder grain microstructures on TEM samples prepared by ultramicrotomy. For 20 hours milling (fig. 3a), the powders are constituted of parallel layers of about $50-100 \mathrm{~nm}$. It has been observed by electronic microprobe that these layers correspond to pure elements lamellae. After 80 hours milling, microstructure is optically homogeneous (fig.3b). 


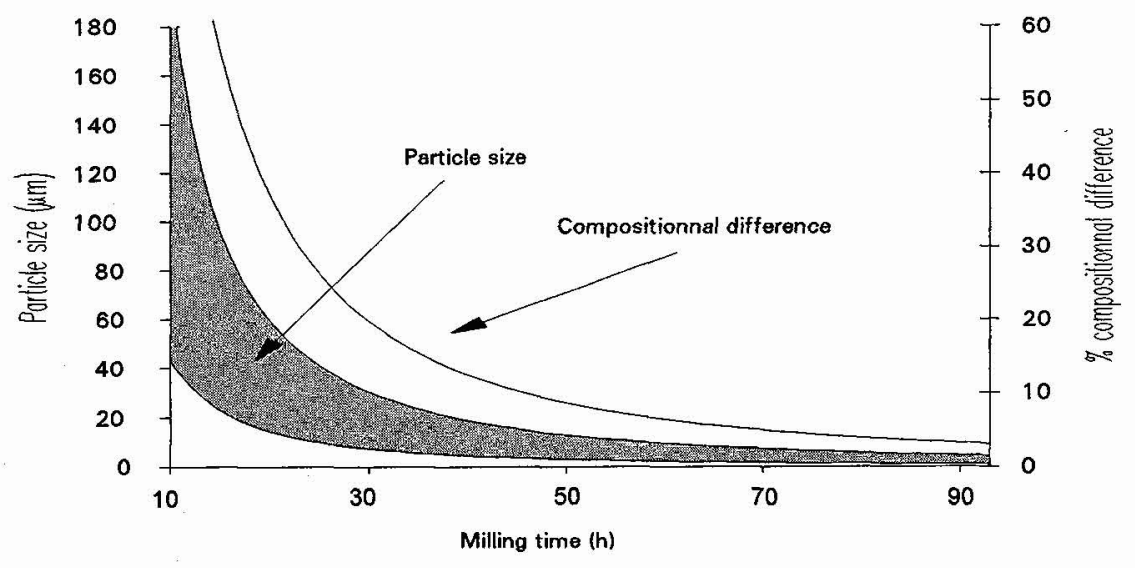

Fig.2 : Macroscopic powder characteristics versus milling time
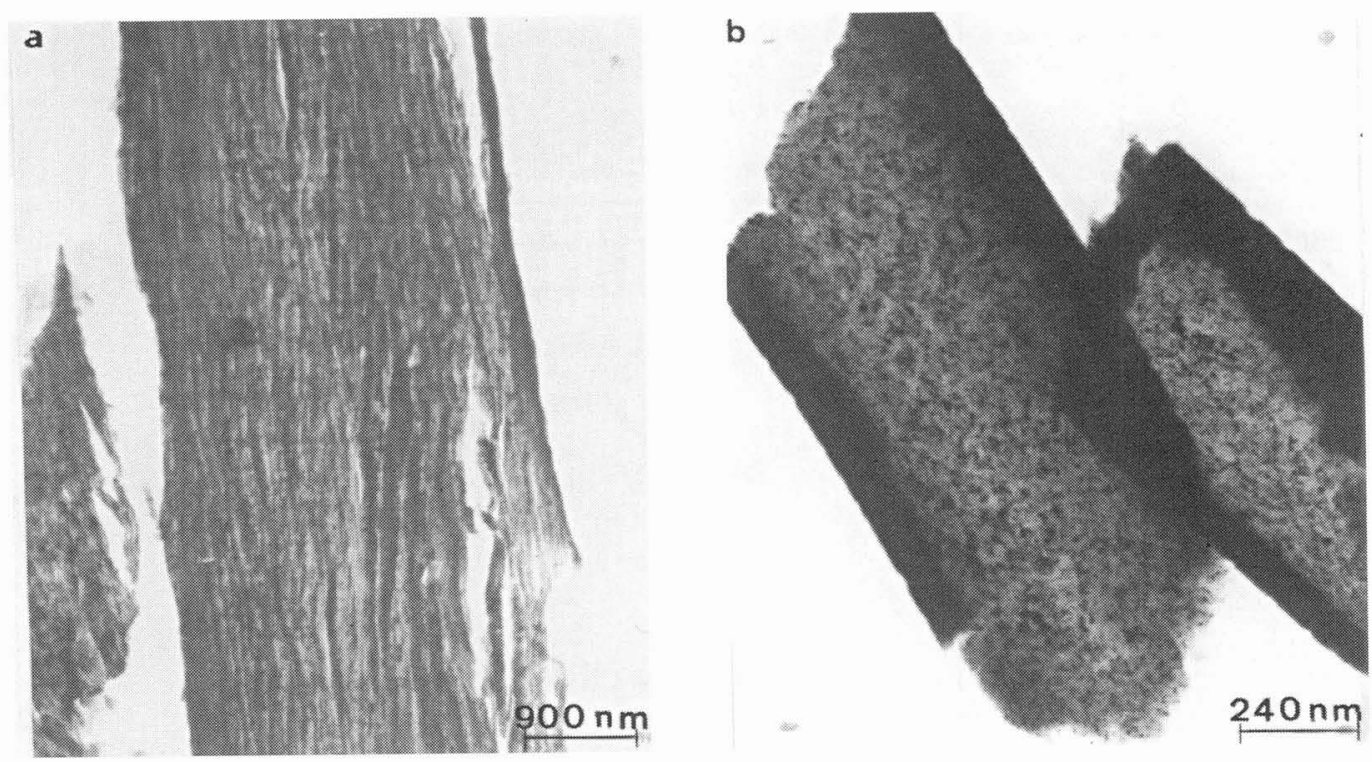

Fig. 3 : TEM photographs of ultramicrotome sections of powder grain after milling under air (a: $20 \mathrm{~h}, \mathrm{~b}: 80 \mathrm{~h}$ )

\subsection{Composition}

Chemical analysis has confirmed that the global composition of the milled powder corresponds to the expected one. STEM-EDS allowed determination of the local compositional homogeneity of an ultramicrotome cut. The compositional difference $(\%)$ between measured and nominal $\mathrm{Cr} / \mathrm{Fe}$ ratio was determined locally for different milling times. Results are given in fig. 2

Because of the similarity in $\mathrm{Fe}$ and $\mathrm{Cr}$ cristallographic structure, the superimposition of their diffraction peaks and their absorption coefficients, the monitoring of phases transformations with milling time by XRD analysis was uneasy. $\mathrm{Fe}, \mathrm{Cr}$, and $\mathrm{FeCr}$ peaks were separated using a deconvolution program. The peak intensity was observed to decrease with simultaneous broadening and shifting. After 40 milling hours, Fe and $\mathrm{Cr}$ could no longer be separated, and only one phase could be identified as $\mathrm{FeCr}$ solid solution [10]. 


\subsection{Microstructure}

The broadening of XRD peaks with increasing milling time can be understood due to both strain and crystallite size reduction. This refinement of matrix microstructure has been confirmed by dark field TEM examinations (fig.4a). At the first stage of milling, mean crystallographic grain size is about $100 \mathrm{~nm}$. After continued milling (fig.4b), the final grain size becomes ten times smaller (fig.5). The transition between crystallized and microcrystallized structure is evidenced by diffraction patterns of fig. 6 .
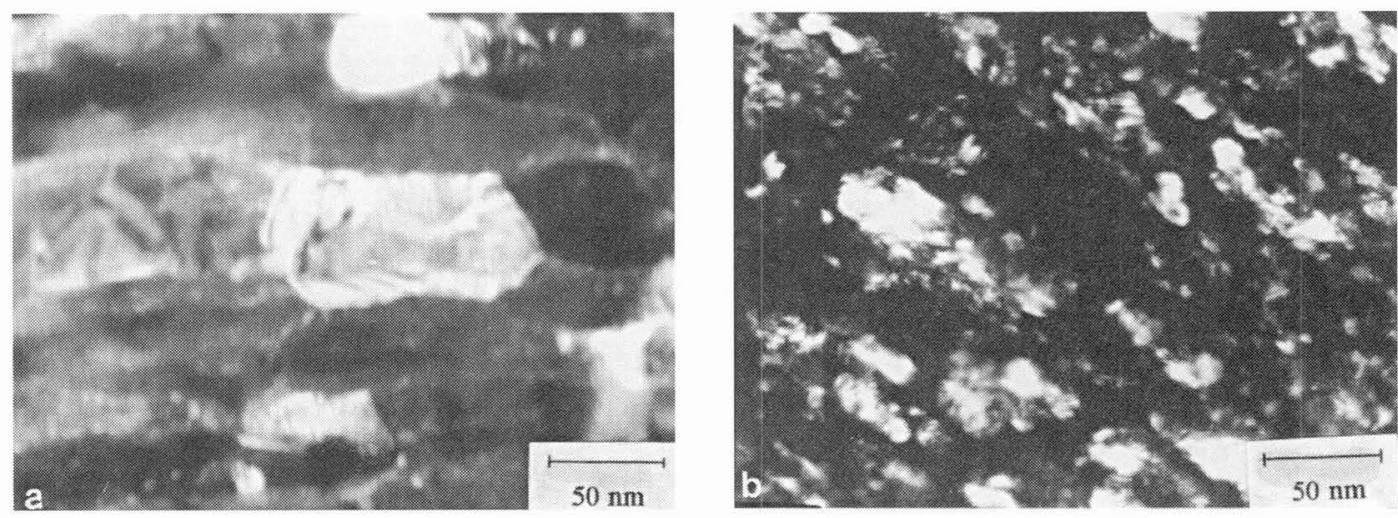

Fig.4 : Dark field TEM photographs of milled powders (a: $20 \mathrm{~h}, \mathrm{~b}: 40 \mathrm{~h}$ )

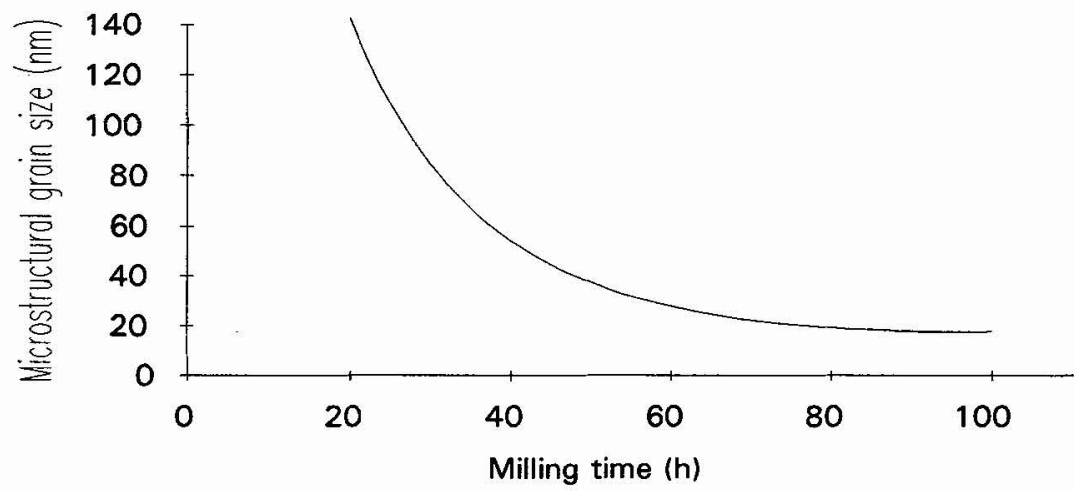

Fig.5 : Microscopic powder characteristics versus milling time

The results obtained from the different characterization techniques show that 40 hours is an optimum time for milling under air:

- the powder grain and crystallite size remain relatively constant after 40 hours,

- the chemical composition is nearly homogeneous and pure $\mathrm{Fe}$ and $\mathrm{Cr}$ phases are no longer observable by XRD. Hot consolidation (extrusion, rolling, HIP) of the powders will smooth any residual compositional heterogeneities.

Some experiments performed under an argon atmosphere have shown that, in this case, chemical homogeneity and crystallite size are identical for 40 hours milling. Otherwise, powder grains are elongated and ten times bigger. 

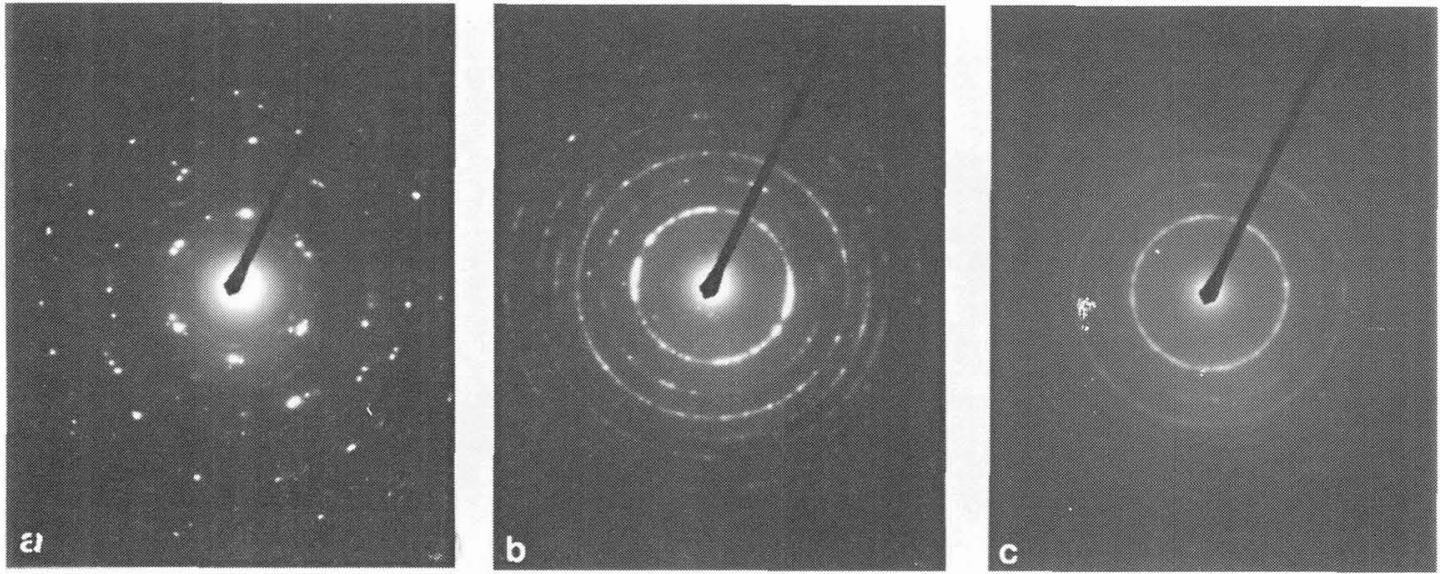

Fig.6 : Diffraction patterns of milled powders (a: $20 \mathrm{~h}, \mathrm{~b}: 40 \mathrm{~h} ; \mathrm{c}: 100 \mathrm{~h}$ )

\section{CHARACTERIZATION OF CONSOLIDATED MATERIALS}

After milling 40 hours under argon atmosphere, powders were canned and compacted 3 hours at $920^{\circ} \mathrm{C}$. TEM samples were prepared by conventionnal methods.

Submicronic matrix structure was generally observed although several microns grains regions could be found. Using the carbon replicas technique, two kinds of dispersoids were observed in the densified material. The biggest ones $(50-200 \mathrm{~nm})$, essentially aligned in some of the grain boundaries, have been identified by electronic diffraction as $\mathrm{Ti}(\mathrm{C}, \mathrm{N})$ compounds (fig.7). The distance between these alignments corresponds approximatively to as-milled powders dimensions. These compounds can result from powder grains superficial contamination when handling under air before canning. The second dispersion, too small to allow electronic diffraction $(10-20 \mathrm{~nm})$, was analysed by energy dispersive spectroscopy (EDS) as complex $\underline{Y}, \mathrm{Ti}, \mathrm{Fe}$ oxides (fig.8).
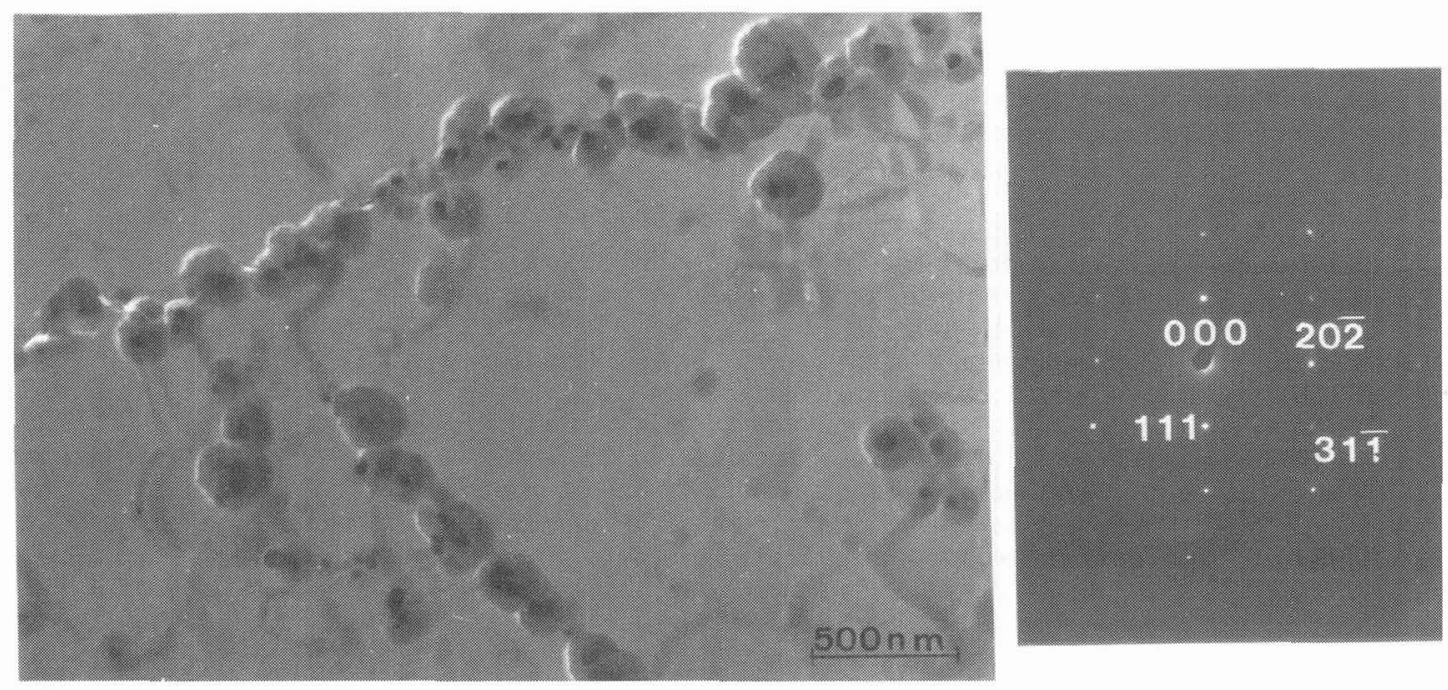

Fig.7 : TEM photographs of Ti (C, N) dispersoids 


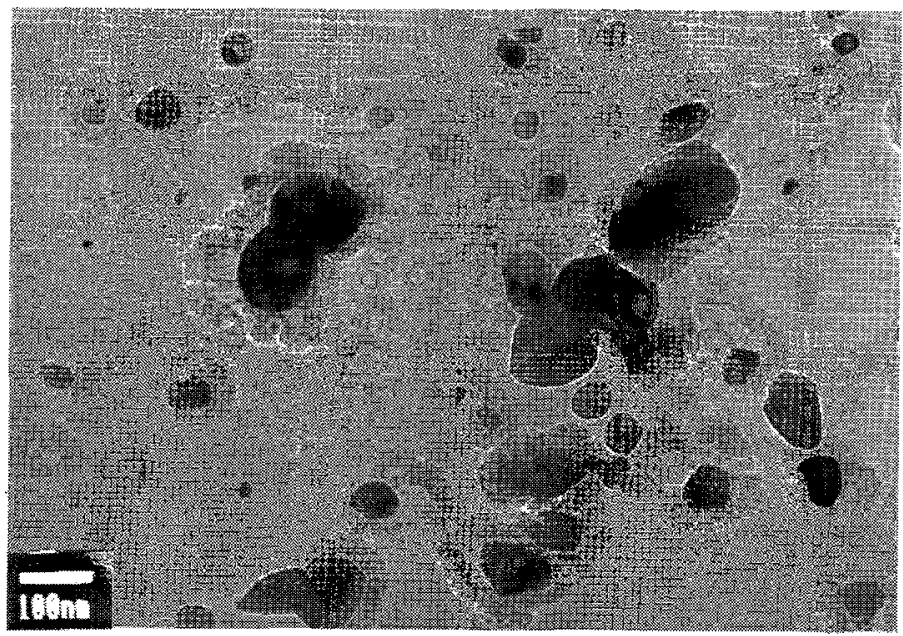

Fig.8 :TEM photographs of $(10-20) \mathrm{nm} \underline{\mathrm{Y}}, \mathrm{Ti}, \mathrm{Fe}$ oxides

\section{CONCLUSION}

Fe-Cr-Ti-Mo ferritic steel reinforced by yttrium oxide dispersion has been elaborated from elemental powders by mechanical alloying in an attritor mill.

Macroscopic and microstructural evolutions of the material have been studied by SEM, TEM, EDS and XRD for milling times ranging from 12 to 100 hours:

- after short milling time, powders are composed of 50-200 $\mu \mathrm{m}$ elongated grains showing a lamellar structure corresponding to the stacking of elemental $\mathrm{Fe}$ and $\mathrm{Cr}$ layers,

- after milling time, particles are nearly equiaxed with a granulometry of 5-10 $\mu \mathrm{m}$. Material composition is homogeneous at a very fine scale. Crystallite size is reduced to $20 \mathrm{~nm}$.

It has been demonstrated that 40 hours is an optimum milling duration afterwhich material compositional and structural changes are small.

Two kinds of reinforcing particles have been observed by TEM on HIP compacted powders:

$-\mathrm{Y}_{2} \mathrm{O}_{3}$ ultrafine particles $(10-20 \mathrm{~nm})$ associated with $\mathrm{Ti}$ and $\mathrm{Fe}$ are dispersed inside the grains,

- $50-200 \mathrm{~nm} \mathrm{Ti}(\mathrm{C}, \mathrm{N})$ compounds are alignated in the grain boundaries.

\section{REFERENCES}

[1] BENJAMIN, J.S., "Mechanical Alloying", Sci. Am., 234, (1976), 40.

[2] HACK, G.A.J., "Developments in the production of oxide dispersion strengthened superalloys", Powder metallurgy, 27,2, (1984), 73

[3] WEBER, J.H., "High temperature O.D.S. alloys", SAMPE Quarterly, July, (1980), 35

[4] BENJAMIN, J.S., VOLIN, T.E., "The mechanism of MA", Metall. Trans., 5, 8, (1974), 1929.

[5] BROWN, L.M., HAM, R.K., "Strengthening methods in crystals", Elsevier, Amsterdam, (1971), 9

[6] DE WILDE, L., GEDOPT, J., "Pilot scale fabrication of ODS ferritic alloy components for fast breeder reactor fuel pins", Materials for nuclear reactor core applications, BNES, London, (1982).

[7] LITTLE, E.A., MAZEY, D.J., HANKS, W., "Effects of ion irradiation on the microstructure of an ODS ferritic steel", Scripta metall. and Mat., 25, (1981), 1115.

[8] WHITTENBERGER, J.D., "Elevated temperature mechanical properties of the iron base ODS alloy MA 956 bar", Metall. Trans, 12A, 5, (1981), 845.

[9] ALAMO, A., REGLE, H, PONS, G., "Microstructure and texture of ODS ferritic alloys obtained by MA", International Symposium on MA, Kyoto, Japan, May 7-10, (1991).

[10]BODART, M., MORET, F., BACCINO, R., "Effects of mill parameters on powder microstructure in the mechanical alloying of Fe-based alloys", Advances in powder metallurgy \& particulate materials, Novel Powder Processing (vol.7), PM'92, San Francisco; June, (1992), 207 